\title{
Phytochemical and Antioxidant analysis of the leaf extract of Malaysian Medicinal Plant Abroma augusta L.
}

\author{
P. SUNITHA*, N. SATHYANARAYANA, V. C. SURESH ${ }^{1}$, S. SREERAMANAN² AND R. XAVIER ${ }^{1}$ \\ Faculty of Medicine, AIMST University, Bedong, Malaysia, ${ }^{1}$ Faculty of Applied Sciences, AIMST University, Bedong, ${ }^{2}$ School \\ of Biological Sciences, Universiti Sains Malaysia, Penang, Malaysia
}

\section{Sunitha, et al.: Malaysian Medicinal Plant Abroma augusta L}

\begin{abstract}
Abroma augusta has been used in folk Indian system of alternative medicine, for treating various conditions like diabetes mellitus, amenorrhea, nervous dysmenorrhea, antifertility and dermatitis. The objective of present study was to evaluate the phytochemical content, antioxidant activity, polyphenolic compounds and elemental analysis of the ethanol extract of leaves of $\boldsymbol{A}$. augusta of Malaysian descent for the first time. Qualitative analysis of $\boldsymbol{A}$. augusta leaf extract showed the presence of reducing sugars, alkaloids, tannins, phenols and flavonoids. Total phenolic and flavonoid content were found to be $15.76 \pm 0.16 \mathrm{mg} / \mathrm{g}$ gallic acid equivalent and $8.6 \pm 0.11 \mathrm{mg} / \mathrm{g}$ quercetin equivalent, respectively. Antioxidant activity showed that the $\mathrm{IC}_{50}$ value was $790 \pm 3.6 \mu \mathrm{g} / \mathrm{ml}$ and $367.6 \pm 16.9 \mathrm{mg} / \mathrm{g}$ ferrous sulfate equivalent by 2,2 -diphenyl-1-picrylhydrazyl and ferric reducing antioxidant power assay, respectively. Presence of gallic acid, quercetin, ascorbic acid and essential elements such as calcium (Ca), copper (cu), iron (Fe) manganese (Mn), lead (Pb), zinc ( $\mathrm{Zn})$, nickel ( $\mathrm{Ni}$ ), magnesium ( $\mathrm{Mg}$ ) and sodium (Na) were determined by high performance liquid chromatography and atomic absorption spectroscopy, respectively. This study provided ample evidences that $A$. augusta is a rich source of polyphenolic compounds with good antioxidant activity. Thus, A. augusta may be a great natural source for the establishment of new drugs.
\end{abstract}

Key words: $A$. augusta, polyphenols, HPLC, DPPH, FRAP, AAS

Abroma augusta (Malvaceae) is commonly known as Ulatkambal in Hindi, Devil's cotton in English and Kepashantu in Bahasa Malayu. It is widely distributed in Asia, South and East Africa and Australia ${ }^{[1]}$. The species is of Indo-Malaysian origin and it is found in Perak, Pahang, Selangor, and Kelantan States of Peninsular Malaysia. A. augusta is a small shrub with a long history of medicinal use in Ayurveda system. In India, the mother tincture of $A$. augusta is widely used in homeopathic medicine to treat uterine disorders and diabetes mellitus. Its root-bark is highly useful as uterine tonic and to treat amenorrhoea, dysmenorrhea, abortifacient and antifertility. Leaves are used for diabetes, rheumatic pains and headache with sinusitis. Leaves and stem are used as demulcent. Cool water extract of fresh leaves and stems is very efficacious in gonorrhoea $^{[2-4]}$.

The free radical or reactive oxygen species (ROS) overproduction contribute oxidative stress in the human body, which leads to damage of proteins, lipids and DNA that is associated with chronic degenerative diseases such as hypertension, coronary

*Address for correspondence E-mail: drsunithaaimst@gmail.com

January-February 2018 artery diseases, diabetes and cancer. Antioxidants are manufactured within the body and supplemented from the foods such as vegetables, fruits, nuts and seeds ${ }^{[5,6]}$. Many plant derived medicines are rich in phenolic, flavonoids, alkaloids and tannins, which possess strong antioxidant activity, thus protecting the body from various degenerative diseases ${ }^{[7,8]}$. Globally, there has been a growing interest for exploring the untapped reservoir of medicinal plants. It is learnt from the literature survey, no much studies have been directed towards understanding the basis of the medicinal properties of $A$. augusta. Thus, this pioneering study would shed light on explaining the medicinal properties of this unexplored plant. Hence, the present study is focused on evaluation of the phytochemical content

This is an open access article distributed under the terms of the Creative Commons Attribution-NonCommercial-ShareAlike 3.0 License, which allows others to remix, tweak, and build upon the work non-commercially, as long as the author is credited and the new creations are licensed under the identical terms

Accepted 28 December 2017

Revised 09 May 2017

Received 11 January 2017

Indian J Pharm Sci 2018;80(1):192-198 
and antioxidant activity of the leaves of $A$. augusta of Malaysian origin.

The whole plant of $A$. augusta contains secondary metabolites including steroids, alkaloids, triterpenes, flavonoids, phenols, megastigmanes, benzohydrofurans and their glycosides and phenylethanoid glycosides ${ }^{[9]}$. The leaves of $A$. augusta are reported to contain octacosanol, taraxerol, sitosterol acetate, lupeol, an aliphatic alcohol $\left(\mathrm{C}_{32} \mathrm{H}_{66} \mathrm{O}\right)$ and mixture of long chain fatty diols. Recently it was reported that the active constituent of the A. augusta was identified as abromine and was mainly responsible for antihyperglycaemic activity ${ }^{[10]}$.

\section{MATERIALS AND METHODS}

The leaves of A. augusta were collected from Batu Kurau, Perak, Malaysia. The plant was identified and authenticated in the Department of Biotechnology, Faculty of Applied Sciences, AIMST University, Semeling, Bedong, Kedah, Malaysia. 2,2-diphenyl-1picrylhydrazyl (DPPH), $\mathrm{AlCl}_{3}$, ferric chloride $\left(\mathrm{FeCl}_{3}\right)$, Folin-Ciocalteu reagent, ferrous sulphate $\left(\mathrm{FeSO}_{4}\right)$, hydrochloric acid $(\mathrm{HCl})$, sodium carbonate $\left(\mathrm{Na}_{2} \mathrm{CO}_{3}\right)$, trichloroacetic acid, potassium acetate, quercetin, gallic acid (GA), rutin hydrate $(\mathrm{RH})$, ascorbic acid (AS), nitric acid $\left(\mathrm{HNO}_{3}\right)$, chloroform and ethanol were purchased from Sigma-Aldrich Chemical Co., USA. All other reagents and chemicals used were of analytical grade.

\section{Preparation of an extract of leaves of $\boldsymbol{A}$. augusta:}

Shade-dried leaves of $A$. augusta were finely powdered

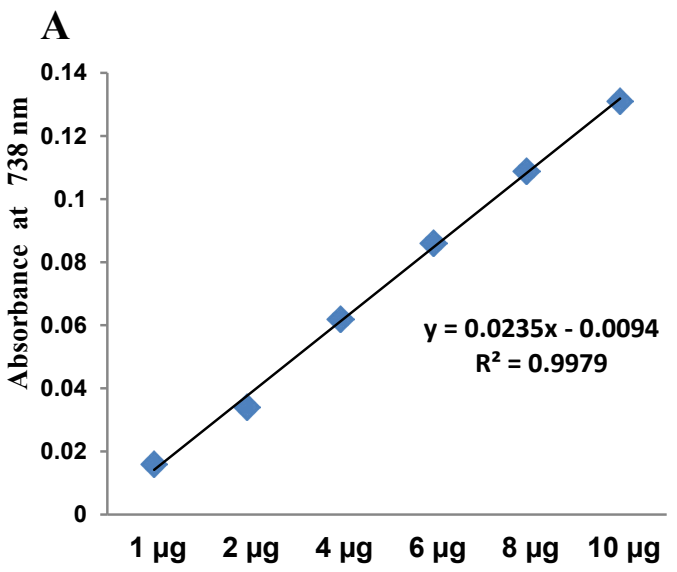

Concentration $\mu \mathrm{g} / \mathrm{ml}$ with a blender and used for the preparation of ethanol extract. The ethanol extract was prepared by maceration method and concentrated using a rotary evaporator. The extract was dried under reduced pressure at controlled temperature $\left(40^{\circ}\right)$.

\section{Phytochemical screening:}

The ethanol extract of $A$. augusta leaf (EEAAL) was screened for the presence of phytochemical constituents such as reducing sugars, tannins, alkaloids, phenols and flavonoids following the standard procedures ${ }^{[11]}$.

\section{Determination of total phenolic content:}

Total phenols were estimated by the Folin-Ciocalteau method with slight modifications ${ }^{[12]}$. Different concentrations of EEAAL ranging from 125 to $500 \mu \mathrm{g} / \mathrm{ml}$ was prepared and $1.5 \mathrm{ml}$ Folin-Ciocalteau reagent was added to the extract and incubated at room temperature for $5 \mathrm{~min}$ and added $4 \mathrm{ml}$ of $20 \% \mathrm{Na}_{2} \mathrm{CO}_{3}$ solution. The contents were made up to $10 \mathrm{ml}$ with distilled water and incubated at room temperature for $30 \mathrm{~min}$ and the absorbance was recorded at $738 \mathrm{~nm}$. GA was used as the standard. The total phenolic content of EEAAL was expressed in terms of GA equivalents (GAE; fig. 1A) $)^{[13]}$.

\section{Determination of total flavonoid content:}

The aluminium chloride $\left(\mathrm{AlCl}_{3}\right)$ calorimetric method was used to determine the amount of flavonoids in EEAAL by slight modification. Varying concentrations of EEAAL ranging from $250-2000 \mu \mathrm{g} / \mathrm{ml}$ was prepared. The absorbance was measured at $415 \mathrm{~nm}$ and quercetin used as a standard. The flavonoid content of EEAAL

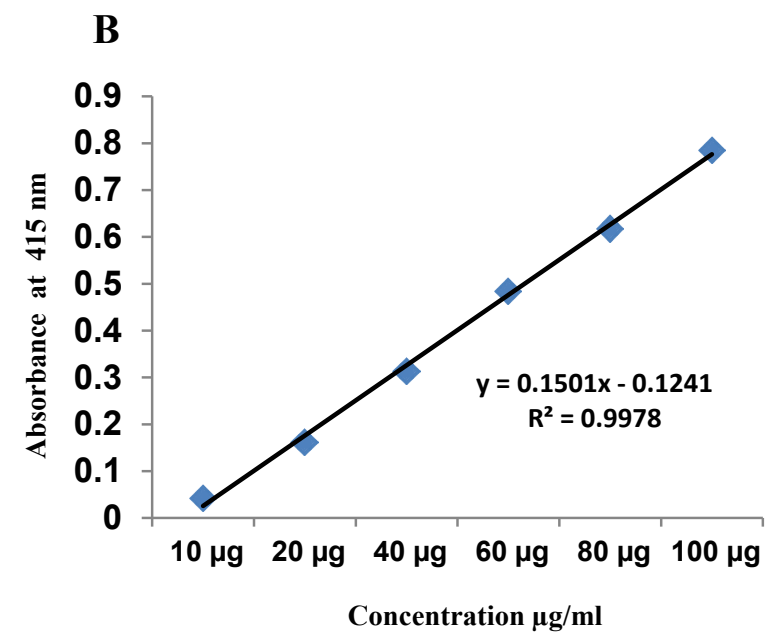

Fig. 1: Total phenolic and flavonoid content for standard gallic acid and quercetin A. Total phenolic content for standard gallic acid, values expressed in terms of gallic acid equivalent; B. Total flavonoid content for standard quercetin, values expressed in terms of quercetin equivalent 
was expressed in terms of quercetin equivalents (QUE; fig. 1B) ${ }^{[14,15]}$.

\section{DPPH free radical scavenging assay:}

The DPPH is a stable free radical and widely used to assess the radical scavenging activity of antioxidant compounds $^{[12]}$. This method is based on the reduction of DPPH in ethanol solution in the presence of a hydrogen donating antioxidant due to the formation of the non-radical form DPPH-H ${ }^{[16]}$. This transformation results in a colour change from purple to yellow, which is measured spectrophotometrically at $517 \mathrm{~nm}$. The reaction mixture $(3 \mathrm{ml})$ consists of $1 \mathrm{ml}$ of DPPH in ethanol $(0.3 \mathrm{mM}), 1 \mathrm{ml}$ of the extract and $1 \mathrm{ml}$ of ethanol. The mixture was incubated for $30 \mathrm{~min}$ in the dark, and then the absorbance was measured at $517 \mathrm{~nm}$ using quercetin as standard (fig. 2A) ${ }^{[17]}$. The percent inhibition was calculated using the Eqn., inhibition $(\%)=\left(A_{0}-A_{1} / A_{0}\right) \times 100$, where, $A_{0}$ is the absorbance of control and $A_{1}$ is the absorbance of the sample. Each experiment was carried out in triplicate and the results are expressed as mean $\%$ antiradical activity.

\section{Ferric reducing antioxidant power (FRAP) assay:}

FRAP was used to measure the direct electron donating ability of extract ${ }^{[18]}$. FRAP assay was performed according to the method of Benzie and Strain (1999) with slight modifications. A standard curve was prepared using different concentrations (0.156-5 mg/ml) of $\mathrm{FeSO}_{4} 7 \mathrm{H}_{2} \mathrm{O}$ (fig. 2B). The sample concentration ranging from $0.156-5.0 \mathrm{mg} / \mathrm{ml}$ were added to FRAP reagent. The blank was prepared using FRAP reagent and ethanol. The contents were incubated in a water bath for $30 \mathrm{~min}$ at $37^{\circ}$ and the absorbance of the samples were determined at $593 \mathrm{~nm}$. The results were expressed in $\mathrm{mg} / \mathrm{g} \mathrm{FeSO}_{4}(\mathrm{E})$. All experiments were performed in triplicate ${ }^{[19]}$.

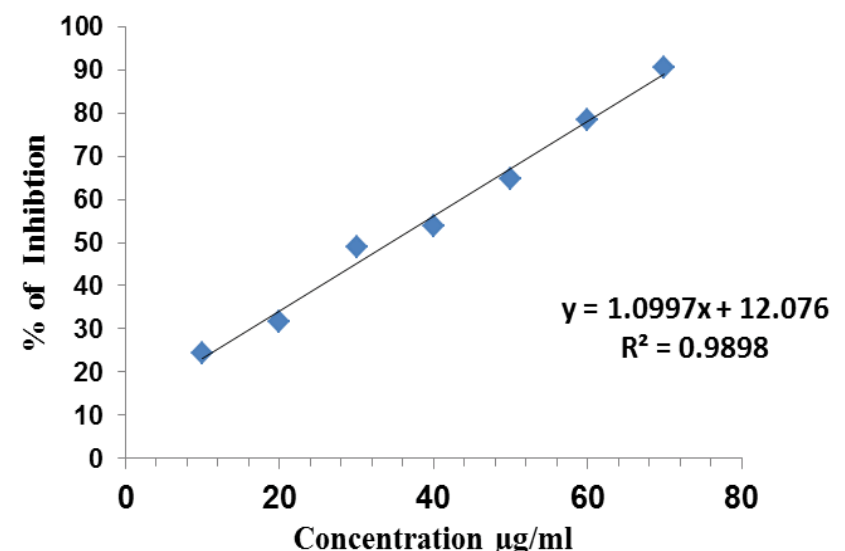

High performance liquid chromatography (HPLC) analysis:

Standards of GA $(98.0 \%)$, RH $(98.1 \%)$, quercetin (98.5\%) and AS (99.0 \%) were purchased from SigmaAldrich, USA. The HPLC grades of Acetonitrile, ammonium acetate and methanol were purchased from Merck, Germany. All other chemicals used were of analytical grade. The standard and the EEAAL stock solutions were prepared at $1 \mathrm{mg} / \mathrm{ml}$ then filtered with Whatman filter paper and used for analysis.

\section{Chromatographic conditions:}

The method described by Laghari et al., was adopted with slight modifications ${ }^{[17]}$. The chromatographic separation was achieved on a Shimadzu high-pressure liquid chromatography system equipped with a binary LC-20AD solvent delivery system, SPD-20A photodiode array detector and SIL-20ACHT injector with $100 \mu 1$ loop volume. Thermo C18 $(250 \times 4.6 \mathrm{~mm}$ i.d., $5.0 \mu$ ) column was used for analysis (Thermo scientific, USA). The mobile phase consisted of a mixture of acetonitrile, $5 \mathrm{mM}$ ammonium acetate (40:60; pH 4.5) and was delivered at a flow-rate of $1 \mathrm{ml} / \mathrm{min}$ with detection at $278 \mathrm{~nm}$. The mobile phase was filtered through a $0.45 \mu \mathrm{m}$ membrane filter.

The volume of sample injected was $25 \mu 1$. Standard peaks for quercetin, rutin, GA and AS were recorded. Peaks for all components were automatically integrated using the LC solution version 1.25 data acquisition system (Shimadzu Corporation, Japan). All chromatography analysis was carried out at ambient temperature.

\section{Atomic absorption spectroscopy (AAS):}

Elemental analysis of $A$. augusta was performed using AAS. A crucible containing $5 \mathrm{~g}$ of dried A. augusta leaf

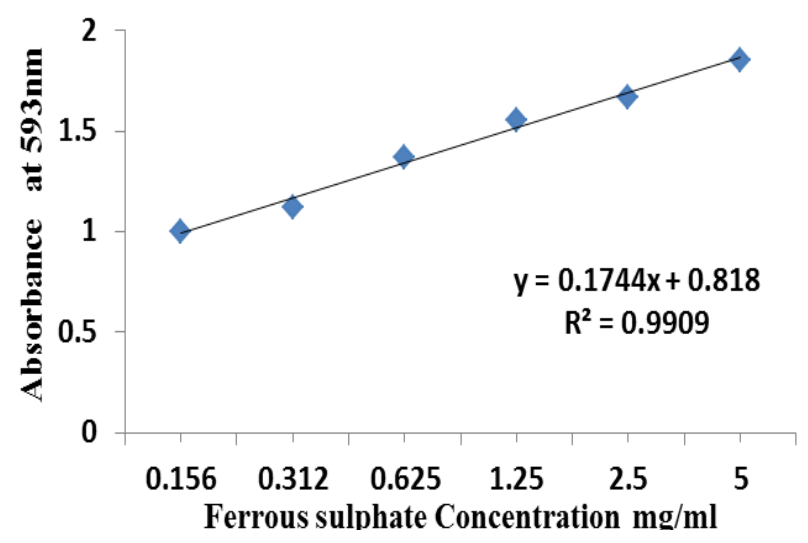

Fig. 2: DPPH radical scavenging activity quercetin (A) and FRAP assay of ferrous sulphate (B) 
sample was placed in a hot furnace at $600^{\circ}$ for $3 \mathrm{~h}$. After cooling the sample in a desiccator, $0.5 \mathrm{~g}$ of the ashed sample was mixed with $5 \mathrm{ml}$ each of distilled water, concentrated $\mathrm{HNO}_{3}$ and perchloric acid $\left(\mathrm{HCIO}_{4}\right)$ and transferred into the digestion block inside a fume cupboard at $150^{\circ}$ for $90 \mathrm{~min}$. The temperature was then increased to $230^{\circ}$ for $30 \mathrm{~min}$ and then reduced to $150^{\circ}$, followed by the addition of $1 \mathrm{ml}$ of $\mathrm{HCl}$ to the tubes immediately. The concentrated digest was not allowed to cool to room temperature to prevent the formation of insoluble precipitate (potassium per chlorate). Water was added to the tube to make up to mark and the content was mixed and filtered. The resulting solution was used for the elemental analysis using AAS (AAnalyst 400 Model) at an appropriate wavelength, temperature and lamp-current for the different elements ${ }^{[20]}$. The elements calcium $(\mathrm{Ca})$, copper $(\mathrm{Cu})$, iron $(\mathrm{Fe})$, manganese $(\mathrm{Mn})$, lead $(\mathrm{Pb})$, zinc $(\mathrm{Zn})$, nickel $(\mathrm{Ni})$, magnesium $(\mathrm{Mg})$, and sodium $(\mathrm{Na})$ were determined.

\section{Statistical analysis:}

The experiments were performed in triplicate and the data were statistically analysed as mean \pm SD. All graphs were plotted using MS Excel ${ }^{\circledR}$ software 2010.

\section{RESULTS AND DISCUSSION}

Malvaceae family includes an array of medicinal plants. Preliminary qualitative phytochemical screening of EEAAL showed the presence of reducing sugars, alkaloids, phenols and flavonoids. The quantitative analysis showed the total phenolic and flavonoid content was $15.76 \pm 0.16 \mathrm{mg} \mathrm{GAE} / \mathrm{g}$ and $8.6 \pm 0.11 \mathrm{mg} \mathrm{QE} / \mathrm{g}$, respectively. A. augusta, a member of Malvaceae family showed significant amount of phenol and flavonoids. A number of studies reported on phenolic and flavonoid content of plants belonging to Malvaceae family. Falguni and Subrata ${ }^{[21]}$ reported the total phenol and total flavonoid content of plants with red $(24.29 \pm 0.47 \mathrm{mgGAE} / \mathrm{g}, 25.50 \pm 3.56 \mathrm{mg} \mathrm{QE} / \mathrm{g})$, pink (13.58 $\pm 0.11 \mathrm{mg} \mathrm{GAE} / \mathrm{g}, 11.75 \pm 2.92 \mathrm{mg} \mathrm{QE} / \mathrm{g})$, white $(10.58 \pm 0.05 \mathrm{mgGAE} / \mathrm{g}, 12.21 \pm 2.80 \mathrm{mgQE} / \mathrm{g})$ and yellow (19.56 $\pm 0.05 \mathrm{mgGAE} / \mathrm{g}, 14.02 \pm 4.92 \mathrm{mg}$ $\mathrm{QE} / \mathrm{g})$ coloured flowers of Hibiscus rosasinensis, respectively ${ }^{[21]}$. The total phenol and flavonoid content in the ethanol extract of the Malva parviflora reported to be $2.44 \mathrm{mg} \mathrm{GAE} / \mathrm{g}$ and $1.07 \mathrm{mg} \mathrm{RHE} / \mathrm{g}$, respectively ${ }^{[22,23]}$. The phenolic and flavonoid content of the water extract of Hibiscus cannabinus were $18.78 \mathrm{mg} \mathrm{GAE} / \mathrm{g}$ and $2.49 \mathrm{mg} \mathrm{RHE} / \mathrm{g}$, respectively ${ }^{[24,25]}$. The nature and content of polyphenolics varies dramatically among plants, which possess beneficial properties, such as antioxidant, immune modulatory actions and anticancer and antibacterial activity ${ }^{[25]}$.

ROS and reactive nitrogen species are the most frequent pro-oxidants, which originate from normal metabolism or induced by UV radiation and different pollutants. The harmful effects are mitigated by intake of antioxidants ${ }^{[26,27]}$. The use of natural antioxidants from plants does not induce adverse effects, while synthetic antioxidants were found to have genotoxic effect ${ }^{[28]}$. Therefore, the research on biological activity and chemical composition of medicinal plants are required to find out the presence of natural antioxidants providing a lead in drug discovery.

The DPPH assay of EEAAL showed considerable $\mathrm{IC}_{50}$ value of $790 \pm 3.6 \mu \mathrm{g} / \mathrm{ml}$ as compared to quercetin $34.5 \pm 2.1 \mu \mathrm{g} / \mathrm{ml}$, which is a well-known antioxidant. The FRAP assay of EEAAL indicated a value of $367.6 \pm$ $16.9 \mathrm{mg} \mathrm{FeSO}_{4} \mathrm{E} / \mathrm{g}$. Individual compounds in the EEAAL were identified by HPLC with the detection wavelength for standards $\mathrm{AS}, \mathrm{GA}$ and $\mathrm{RH}$, quercetin were $254 \mathrm{~nm}$ and $366 \mathrm{~nm}$, respectively. Symmetrical, sharp and well-resolved peaks were observed for the four standards. The elution order and the retention times for RH, quercetin, AS and GA were 3.28, 4.11, 5.19 and 7.25 min, respectively (fig. 3). Comparatively, in EEAAL chromatogram the elution order and retention time for quercetin, AS and GA were 4.336, 5.222 and 7.030 min, respectively (fig. 4). Thus it may be inferred that the antioxidant activity exhibited by EEAAL is mainly due to the presence of quercetin, AS and GA.

AS is the major antioxidant that plays a leading role in disease prevention ${ }^{[29]}$. Similarly, quercetin is a natural flavone derivative with significant scavenging property with antiallergic, antiinflammatory, antitumor, antiviral, hypolipidaemic, cytoprotective and anticarcinogenic properties ${ }^{[30]}$. GA is a polyphenol natural product found in gallnuts, tea leaves known for antioxidative, antiinflammatory, antifungal, anticancer and chemoprotective properties ${ }^{[31,32]}$.

Results of the present study confirmed the presence of considerable amount of polyphenolic compounds through qualitative and quantitative analysis of EEAAL and supported by HPLC analysis. Thus, based on the results it is inferred that the A. augusta is a good source of principal antioxidants, which in turn may play a critical role in prevention of diseases.

Trace elements are essential to play an important role in nutrition, enzyme reaction and various metabolisms ${ }^{[33]}$. Analysis of elemental composition is essential for 


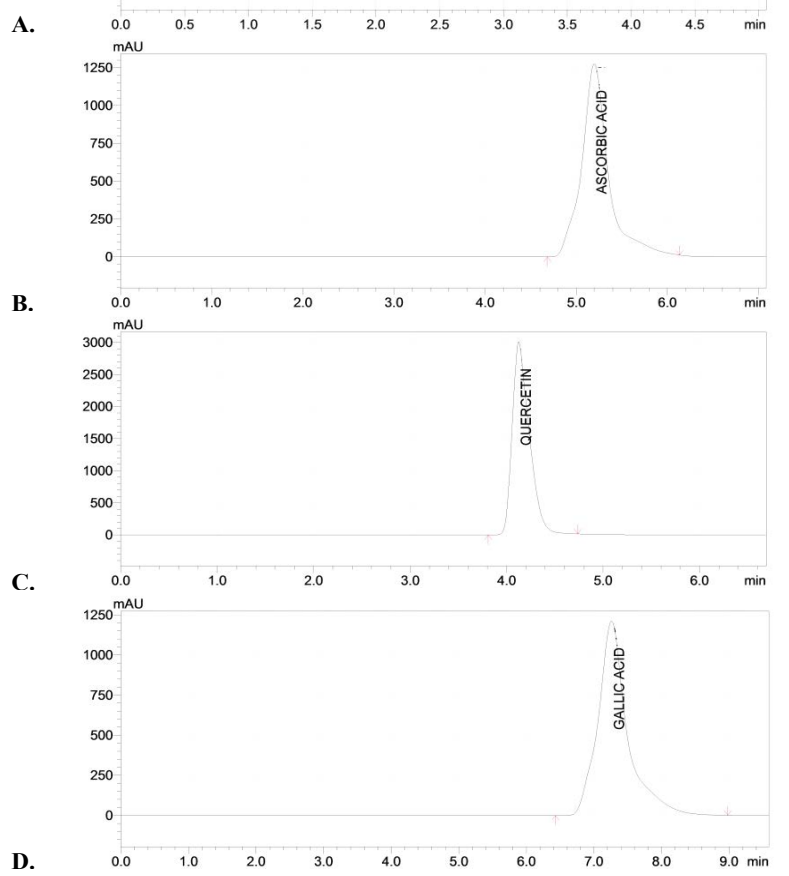

Fig. 3: HPLC chromatograms

HPLC chromatogram of rutin (A), ascorbic acid (B), quercetin (C), gallic acid (D). The elution order and the retention times for rutin, quercetin, ascorbic acid and gallic acid were 3.28, 4.11, 5.19 and $7.25 \mathrm{~min}$, respectively

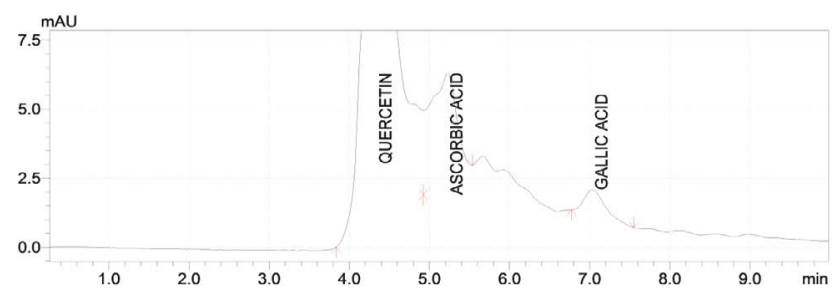

Fig. 4: HPLC analysis of Abroma augusta leaf extract Elution order and retention time for quercetin, ascorbic acid and gallic acid were $4.336,5.222$ and $7.030 \mathrm{~min}$, respectively

widely used medicinal plants. Most of the medicinal plants are found to be rich in one or more elements. The plants are having different levels of the trace elements from different geographical areas. Which is due to the variation in soil types, agricultural and industrial activities and local growing conditions such as differences in water, plant interactions, and weather ${ }^{[34,35]}$. The AAS analysis of EEAAL displayed variable concentrations of the different trace elements including $\mathrm{Ca}, \mathrm{Cu}, \mathrm{Fe}, \mathrm{Mn}, \mathrm{Pb}, \mathrm{Zn}, \mathrm{Ni}, \mathrm{Mg}$ and $\mathrm{Na}$ were determined (Table 1) and found to be in the permissible limit defined by $\mathrm{WHO}^{[36]}$. Elements required for different physiological, biochemical and molecular functions in human body ${ }^{[37]}$. Even though these are essential for normal functioning of body they can be harmful and toxic at high concentrations ${ }^{[38]}$. Therefore, elemental analysis is essential for safety of herbal drugs to treat different diseases.

Trace elements have been identified as potential factors for improving metabolic disorders including diabetes mellitus ${ }^{[39]}$. some trace elements, such as $\mathrm{Cr}$, $\mathrm{Zn}, \mathrm{Se}, \mathrm{V}, \mathrm{Mg}$ and $\mathrm{Mn}$ act as cofactors of antioxidative enzymes and play an important role in protecting the pancreatic $\beta$-cells of islets of Langerhans, which are sensitive to free radical damage ${ }^{[40,41]}$.

Calcium is required for membrane permeability, excitability, transmission of nerve impulses, muscle contraction, blood clotting and hardness to bones and teeth. Copper plays a vital role in the formation of the heme ${ }^{[42]}$. It is also necessary for myelin sheath formation in the nervous system ${ }^{[43]}$. Iron is an important component of hemoglobin, cytochromes, myoglobin, peroxidise and electron transport ${ }^{[42]}$. Manganese is required for normal metabolism of lipid, protein and carbohydrate and also required for synthesis and secretion of insulin ${ }^{[44]}$. It is also a micro component of metalloenzymes such as arginase, glutamine synthetase, phosphoenolpyruvate decarboxylase, manganese superoxide dismutase, galactotransferase of connective tissue biosynthesis, urea formation and it aids in defence mechanisms against free radicals ${ }^{[42,45]}$.

Magnesium is a cofactor of various enzymes in carbohydrate oxidation and also helps in insulin secretion, transport of glucose that helps in regulation of blood glucose ${ }^{[46,47]}$. Zinc acts as a catalyst for variety of enzymes, including the alcohol dehydrogenase, ribonucleic polymerases, alkaline phosphate and carbonic anhydrase. It is necessary for skin integrity, bone metabolism and growth ${ }^{[48]}$. Sodium maintains isoosmolality with plasma and maintains the $\mathrm{pH}$ of blood

TABLE 1: ATOMIC ABSORPTION SPECTROSCOPY (AAS) ANALYSIS OF ABROMA AUGUSTA LEAF

\begin{tabular}{lc}
\hline Metals & $\mathrm{mg} / \mathrm{ml}$ \\
\hline Calcium (Ca) & $0.819 \pm 0.103$ \\
Copper (Cu) & $0.744 \pm 0.198$ \\
Iron (Fe) & $0.372 \pm 0.012$ \\
Manganese $(\mathrm{Mn})$ & $0.201 \pm 0.032$ \\
Lead (Pb) & $0.310 \pm 0.009$ \\
Zinc ( $\mathrm{Zn})$ & $0.498 \pm 0.016$ \\
Nickel $(\mathrm{Ni})$ & $0.047 \pm 0.009$ \\
Magnesium $(\mathrm{Mg})$ & $0.610 \pm 0.089$ \\
Sodium (Na) & $0.372 \pm 0.001$ \\
\hline
\end{tabular}


within normal limit. It is also useful in conduction of nervous impulses, muscle contraction and conduction of impulse in the heart ${ }^{[49,50]}$. Thus, it is shown that A. augusta is a good source of trace elements that are essential for the normal physiological and biochemical functions to maintain a healthy life.

The present study results can be concluded that this plant showed the presence of significant amount of phenols, flavonoids and important trace elements were within the permissible limit, which directly influence the quality of secondary metabolites. The present study also confirmed the antioxidant properties of EEAAL through DPPH and FRAP assay, which suggests that the leaves of the plant might be a potential source of natural antioxidants to combat the diseases in which there is an increased free radical production. Further studies are needed in this direction to explore more pharmacological actions of this plant.

\section{Acknowledgements:}

The authors would like to thank the management, AIMST University, Kedah, Malaysia for the financial support to carry out the current research project. This project was funded by AIMST University Internal Research Grant No (AURGC/46/FOM/2013).

\section{Conflict of interest:}

The authors of this article declare no conflict of interest in this study.

\section{Financial support and sponsorship:}

Nil.

\section{REFERENCES}

1. http://www.niscair.res.in/activitiesandservices/products/ wealth-of-indiaFolder2010.pdf.

2. Sha H, Hanif B, Mohammed R, Rowank J. A journal of plants, people and applied Research. Ethnobotany Res Appl 2010;8:61-74.

3. Das S, Datta R, Nandy S. Phytochemical screening and evaluation of antiinflammatory activity of methanol extract of Abroma augusta Linn. Asian Pacific J Trop Dis 2012;2:S114-17.

4. Gupta B, Nayak S, Solanki S. Abroma augusta Linn f: A review. Der Pharmacia Sinica 2011;2:253-61.

5. Santharam E, Ganesh P, Soranam R. Evaluation of in vitro free radical scavenging potential of various extracts of whole plant of Calycopteris floribunda (Lam). J Chem Pharm Res 2015;7:860-4.

6. Gafrikova M, Galova E, Sevcovicova A. Extract from Armora ciarusticana and its flavonoid components protect human lymphocytes against oxidative damage induced by hydrogen peroxide. Molecules 2014;19:3160-72.

7. Uddin G, Rauf A. Phytochemical screening and biological activity of the aerial parts of Elaeagnus umbellate. Sci Res Essays 2012;7:3690-4.

8. Lakshmi GM, Bhuvaneshwari V, Amsaveni R. Antioxidant and antibacterial activity from whole plant of Eclipta alba (L.) An in vitro model. IJBSANS 2015;2:1-8.

9. Saikot FK, Khan A, Hasan MF. Antimicrobial and cytotoxic activities of Abroma augusta Lnn. leaves extract. Asian Pac J Trop Biomed 2012;2(3):1418-1422.

10. Mir SH, Darzi MM, Mir MS. Efficacy of Abroma augusta on biochemical and histomorphological features of alloxaninduced diabetic rabbits. Iranian J Pathol 2013;8(3):153-58.

11. Harborne JB. Phytochemical methods. New Delhi: Springer (India) Pvt. Ltd.; 2005. p. 17.

12. Azlim Almey AA, Ahmed JK, Syed ZI, Mustapha SK, Ayisha MR, Kamarul RK. Total phenolic content and primary antioxidant activity of methanol and ethanol extracts of aromatic plant' leaves. Int Food Res J 2010;17:1077-82.

13. Singleton V, Orthofer, Lamuela R. Analysis of total phenols and other oxidation substrates and antioxidants by means of Folin-Ciocalteu reagent. Methods Enzymol 1999;299:152-78.

14. Kalita P, Barman Tapan K, Pal Tapas K, Kalita R. Estimation of total flavonoids content and antioxidant activities of methanol whole plant extract of Biophytum sensitivum. J Drug Deliv Ther 2013;3:33-7.

15. Kamtekar S, Keer V, Patil V. Estimation of phenolic content, flavonoid content, antioxidant and alpha amylase inhibitory activity of marketed polyherbal formulation. J Appl Pharm Sci 2014;4:61-5.

16. Blois MS. Antioxidant determinations by the use of a stable free radical. Nature 1958;26:1199-200.

17. Shon DH, Kim YC, Oh SH. Hepatoprotective and free radical scavenging effects of Nelumbo nucifera. Phytomedicine 2003; 10:165-9.

18. Zulkifi KS, Abdullah N, Abdullah A, Aziman N, Kamarudin WS. Bioactive phenolic compounds and antioxidant activity of selected fruit peels. ICECB 2012;49:14.

19. Benzie IF, Strain JJ. Ferric reducing/antioxidant power assay: direct measure of total antioxidant activity of biological fluids and modified version for simultaneous measurement of total antioxidant power and ascorbic acid concentration. Methods Enzymol 1999;299:15-27.

20. Laghari AH, Memon S, Nelofar A. Determination of free phenolic acids and antioxidant activity of methanol extracts obtained from fruits and leaves of Chenopodium album. Food Chem 2011;126:1850-5.

21. Falguni S, Subrata D. Evaluation of comparative antioxidant potential of four cultivars of Hibiscus rosa-sinensis L. by HPLC-DPPH method. Free Radicals Antioxidants 2012;2:73-8.

22. Olajide O, Afolayan M, Adewusi AJ, Adeyanju O. Antimicrobial activity and Elemental analysis of Cassia siberiana leaves Using Atomic Absorption Spectrometer. Scholars Research Library. J Nat Prod Plant Resour 2012;2:9-18.

23. Sanghai DB, Kumar SV, Srinivasan KK, Aswatharam HN, Shreedhara CS. Pharmacognostic and phytochemical investigation of the leaves of Malvastrum coromandelianum (L.) Garcke. Anc Sci Life 2013;33:39-44. 
24. Farhan H, Rammal H, Hijazi A, Hamad H. In vitro antioxidant activity of ethanol and aqueous extracts from crude Malva parviflora grown in Lebanon. Asian J Pharm Clin Res 2012;5:234-8.

25. Yusri NM, Chan KW, Iqbal S, Ismail M. Phenolic content and antioxidant activity of Hibiscus cannabinus L. seed extracts after sequential solvent extraction. Molecules 2012;17:12612-21.

26. Paszkiewicz M, Budzynska A, Rozalska B, Sadowska B. The immunomodulatory role of plant polyphenols. Postepy Hig Med Dosw (Online) 2012;66:637-46.

27. Ghosh T, Maity KT, Sengupta P. Antidiabetic and in vivo antioxidant activity of ethanol extract of Bacopa monnieri Linn. Aerial parts: a possible mechanism of action. Iranian J Pharm Res 2008;7:61-8.

28. Ognjanovic BI, Markovic SD, Pavlovic SZ, Zikic RV, StajnAS, Saicic ZS. Effect of chronic cadmium exposure on antioxidant defence system in some tissues of rats: protective effect of selenium. Physiol Res 2008;57:403-11.

29. Chen C, Pearson MA, Gray IJ. Effects of synthetic antioxidants (BHA, BHT and PG) on the mutagenicity of IQlike compounds. Food Chem 1992;43:177-83.

30. Tarnawski M, Depta K, Grejciun D. HPLC determination of phenolic acids and antioxidant activity in concentrated peat extract natural immunomodulator. J Pharm Biomed Anal 2006;41:82-8.

31. Calabro ML, Tommasini S, Donato $\mathrm{P}$. The rutin $/ \beta$ cyclodextrin interactions in fully aqueous solution: spectroscopic studies and biological assays. J Pharm Biomed Anal 2005;36:1019-27.

32. Lopez M, Mart Inez F, Del Valle C, Ferrit M. Study of phenolic compounds as natural antioxidants by a fluorescence method. Talanta 2003;60:609-16.

33. Soong YY, Barlow PJ. Quantification of gallic acid and ellagic acid from longan (Dimocarpus longan Lour.) seed and mango (Mangifera indica L.) kernel and their effects on antioxidant activity. Food Chem 2006;97:524-30.

34. Tamilarasi L. Antimicrobial and anthelmintic efficacy of Aloe vera (Aloe barbadensis Miller). Ph.D. thesis, University of Madras, Chennai. 2014.

35. Anal JMH. Trace and essential elements analysis in Cymbopogon citratus (DC.) stapf samples by graphite furnace- atomic absorption spectroscopy and its health concern. J Toxicol 2014:2014;690758.

36. Kabata-Pendias A. Trace Elements in Soils and Plants. Boca Raton, Florida: CRC Press; 2011.

37. http://apps.who.int/medicinedocs/documents/h1791e/h1791e. pdf.

38. Prashanth L, Kiran Kumar K, Raviteja C, Venkat RR, Krishna PL. A review on role of essential trace elements in health and disease. J Dr NTR Univ Health Sci 2015;4:75-85.

39. Chrzan. Monitoring bioconcentration of potentially toxic trace elements in soils trophic chains. Environ Earth Sci 2016;75:786.

40. Gaur S, Agnihotri R. Trace mineral micronutrients and chronic periodontitis-a review. Biol Trace Elem Res 2016;173:1-14.

41. Ngugi MP, Njagi MJ, Kibiti M. Trace elements content of selected Kenyan antidiabetc medicinal plants research. Int J Curr Pharm Res 2012;4:39-42.

42. Candilish DJ. Minerals. J Am Coll Nutr 2000;17:286-310.

43. Soetan KO, Olaiya CO, Oyewole OE. The importance of mineral elements for humans, domestic, animals and plants: A review. Afr J Food Sci 2010;4:200-22.

44. Tan JC, Burns DL, Jones HR. Severe ataxia, myelopathy and peripheral neuropathy due to acquired copper deficiency in a patient with history of gastrectomy. JPEN J Parenter Enteral Nutr 2006;30:446-50.

45. Kazi TG, Afridi HI, Kazi N. Copper, chromium, manganese, iron, nickel and zinc levels in biological samples of diabetes mellitus patients. Biol Trace Elem Res 2008;12:1-18.

46. Aschner JL, Ascher M. Nutritional aspects of manganese homeostasis. Mol Aspects Med 2005;26:353-62.

47. Chaudhary DP, Sharma R, Bansal DD. Implications of magnesium deficiency in type 2 diabetes: a review. Biol Trace Elem Res 2010;134:119-29.

48. Viktorínová A, Toserová E, Krizko M, Duracková Z. Altered metabolism of copper, zinc and magnesium is associated with increased levels of glycated hemoglobin in patients with diabetes mellitus. Metabolism 2009;58:1477-82.

49. Saracoglu S, Tuzen M, Soylak M. Evaluation of trace element contents of dried apricot samples from Turkey. J Hazard Mater 2009;167:647-52.

50. Wardlaw GM, Hampl JS, Disilvestro RA. Prospectives in nutrition. 6th ed. New York: McGraw-Hill; 2004. 